\title{
TAXONOMIC STUDY FOR THE NEW RECORD OGASTEMMA PUSILLUM (BORAGINACEAE) IN IRAQ
}
M. O. Mousa
Prof.
S. Sh. Shahatha
Prof.

Center of Desert Studies -Herbarium -University of Anbar

Alhuda7730@yahoo.com

\section{ABSTRACT}

During the filed survey of $140-160$ kilometers region and on both sides of the highway west of Ramadi city in the western desert district of Iraq, and in late spring of 2019, confirmed the recorded of the Ogastemma genus for the first time in Iraq, which was characterized by being a monotypic genus belonging to Boraginaceae family and represented by Ogastemma pusillum. After the identification of the species, which was based on the Flora of the neighboring countries, the species was studied taxonomically. The study worked on describing and photographing all the vegetative and floral parts, anatomy of stem, stomatal complex in leaves, and pollen grains. The plant specimens were preserved under the numbers 60264, 60265 in the Iraqi national herbarium. A morphological study showed that there was uniform indumentum of the epidermis of vegetative organs was appressed-hispid, represented by nonglandular trichomes, medium length of 800-1500 micrometer.

Keywords: Plant taxonomy, wild plants, flora of Iraq, western desert.

موسى وشحاذة 735-724:52: 52021 (3) مجلة العلوم الزراعية العراقية

الراسة تصنيفية للنوع Ogastemma pusillum (Boraginaceae) المسجل جديداً في العرق

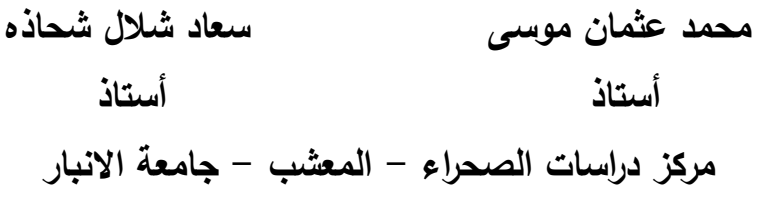

المستخلص

من خلال المسح الميداني لمنطقة الكيلو 140-160 وعلى جانبي طريق المرور السريع غرب مدينة الرمادي ضمن مقاطعة الصحراء الغربية من العرلق، وفي أواخر فصل الربيع من العام 2019 تم تسجيل الجنس Ogastemma لأول مرة في العرلق، والذي يتميز بكونه جنساً وحيذ النوع Monotypic genus يتبع الى العائلة Boraginaceae، متمثلاً بالنوع تو Ogastemma pusillum تصنيفياً فقد عملت الدراسة على وصف وتصوير جميع الاجزاء الخضرية والزهرية، وتشريح الساق، والمعقد الثغري في الأوراق وحبوب اللقاح. أودعت العينات النباتية تحت الارقام 60264 60265 في المعشب الوطني العراقي. اظهرت الدراسة

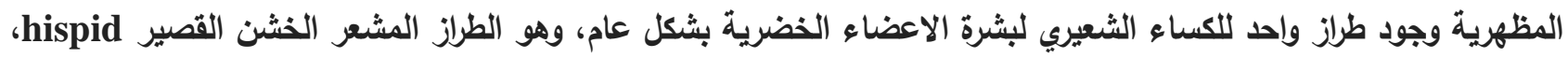
والذي تمثل بشعيرات غير غدية، متوسطة الاطوال، تراوحت بين 800- 1500 مايكروميتر . كلمات مفتاحية: تصنيف النبات، نباتات برية، فلورا العلق، الصحراء الغربية. 


\section{INTRODUCTION}

One of the plant families in Iraq is Boraginaceae that involves 2000 species throughout the world which distributed on 100 genera in tropical and temperate regions (18), in Iraq the family Boraginaceae has been poorly studied, which involves 26 genera (3), and about 93 wild species (5). The genus Ogastemma Brumitt belongs to Boragineae tribe (11), which is located within Boraginoideae subfamily that belongs to Boraginaceae family (20). Ogastemma is characterized for being a monotypic genus, represented by Ogastemma pusillum (Coss. \& Durand ex Bonnet \& Barrate) Brumitt (22), which was distributed in most of the neighboring countries such as Iran (37), Jordan (34), Kuwait (1, 13), Saudi Arabia (15), and Turkey (12), as well as its presence in some nearby countries such as Bahrain (2), Egypt (8), Qatar (29) and United Arab Emirates (18). As for worldwide distribution, Chacon et al., (16) pointed to the presence of the species in Algeria, as Le Floch et al., (21) explained a limited presence of the species in Tunisia, while Verloove (35) said that the Canary Island in Spain included the species, which was one of the desert plants that prefer sandy soils (14). Some of the studies $(25,26,31)$ similar to this study have recorded new species for Iraq, belonging to the same family during the previous years, namely, Echium rauwolfii, Arnebia hispidssim and Paracaryum shepardii respectively, as well as recording of other species such as Lotus garcinii (papilionaceae) within the same distrat (24) . One of the characteristics of the Boraginaceae family is the indumentum of vegetative organs, which researchers have been interested, among them is Taia (33) who studied the types and density of trichomes in 66 species belonging to 20 genera distributed in Egypt. As well as studying the natural content the trichomes of calcium phosphate $(27,36)$. This study assured the occurrence of Ogastemma pusillum in Iraq based on modern collection, to be followed by a morphological description of all organs in order to facilitate future identify of the new record species, to add to the Iraqi plants, note that the seventh volume of the Iraqi Flora, which cared about the Boraginaceae family, unfortunately not issued until this time.

\section{MATERIALS AND METHODS}

In late spring of 2019, during the field trips carried by Herbarium Staff in Center of Desert Studies to study the vegetation of specific locations in western desert, namely the 140160 kilometer region in west of Iraq on both sides of the highway, among the uncommon species collected was Ogastemma pusillum, which has been identified based on some scientific references and neighboring countries Flora $(8,15,16,34,37)$. The species was studied taxonomically, based on fresh plant samples, which included a complete morphological description, as well as anatomical stem characteristics, the pictures of the vegetative and floral organs were placed, as well as a species distribution map (Figure 1). The measurements of vegetative and reproductive organs were completed (Table 1) . The study relied on the hand sections for the preparation of stem slides with the use of safranin stain to coloring of pollen grains and stomatal complex. The specimens (plate 1) were treated and preserved in Anbar University Herbarium (AUH), and in the Iraqi National Herbarium (BAG) under the numbers 60234 and 60235.

\section{RESULTS AND DISCUSSION \\ Newly recorded species}

Ogastemma pusillum (Coss. \& Durand ex Bonnet \& Barratte) Brummitt, Kew Bull. 36:680(1982).

Syn.: Megastoma pusillum Coss. \& Durand ex Balansa, Pl. Algerie 1035(1853), nom. nud., ex Bonnet \& Barratte, Ill. Tunis, t. 11. f. 4-11 (1895). Eritrichium sventeni Sunding, Bull. Jard. Bot. Macarones. 3: 81 (1977). Annual, herb, appressed- hispid, height 10-15 cm., stem erect or ascending, much branched, cylindrical, covered with densely appressed seta, 6-10 x0.1- $0.3 \mathrm{~cm}$. Leaves simple, sessile, exstipulate, alternate- spiral, covered with tubercle- based seta, margin entire, apex acute, based truncate- rounded or attenuate, basal leaves linear- very narrowly lanceolate, dull greenish-yellow, 26-35 x1.5-1.8 mm., cauline leaves narrowly lanceolate or linear, dark green, $12-23 \times 1.3 \times 2.5 \mathrm{~mm}$. (Plate 2). Bracts leaf-like, linear- very narrowly lanceolate, margin entire, apex acute, base 
truncate, densely erect- strigose margins, light green, 6 - 9 x1.1-1.4 mm.. Inflorescences determinate, helicoid cyme, 33-50 mm. number of flowers 7-13, peduncles stem-like, 8-14 x0.8-1.1 mm.. Flowers actinomorphic, pentamerous, pedicels very short, hispid, dark green, 0.4-0.6 x0.3-0.5 mm.. Calyx of 5 gamosepalous at the base, unequal lobes, linear, margin entire, apex acute - rounded, base truncate, hispid, the lower quarter of the sepal is a membranous margin, shiny green, 3.8- 4.4 x2.1-2.3 mm.. Corolla of 5 gamopetalous, tubular- salverform, lobes imbricate, faucal appendages absent, circular, margin sinuate, apex rounded, glabrous, white, 2.4-3.2x 0.8-1.1 mm.. Stamens 5, in one whorl, anthers ovoid-ellipsoid, yellow, dorsifixed attachment with the filaments, longer than the filiform, 0.6- $0.8 \times 0.3-0.5 \mathrm{~mm}$., filaments filiform, yellow, very short, 0.35 0.45x 0.08- $0.10 \mathrm{~m}$.. Pistil 1 , ovary superior, 2 syncarpous, 4 locules, oblate, style single, cylindrical, gynobasic, yellow, 0.32- $0.38 \mathrm{x}$
$0.12 \times 0.15 \mathrm{~mm}$., stigma capitate bilobed, very smooth muricate, dark yellow, $0.15-0.18 \times 0.22-$ $0.25 \mathrm{~mm}$.. The fruiting calyx is like a flowering calyx completely, but it is about $25 \%$ larger. Fruit of 4 schizocarpic nutlets, narrowly ovoid in dorsal view, narrowly triangular in ventral view, densely verrucose, dull yellow-brown, 1.3-1.7 x0.7 -0.9 mm., the taxonomic importance of the nutlets were clarified by Hammouda et al. (17), who confirmed the stability of their shapes and sizes without change, especially the ornamentation. Seed single, pyriform, glabrous, shiny yellow, 1.1-1.4x 0.6- $0.8 \mathrm{~mm}$. (Plate 3). Pollen grains single, tricolporate, semicircular in equatorial view, deltoid in polar view, angulaperturate, white- light yellow, small size (Plate 4), equatorial axis 12.7- $13.8 \mu \mathrm{m}$., polar axis 11.6-12.8 $\mu \mathrm{m}$.. AlShehbaz (6) mentioned the importance of pollen grains in isolating the species of Boraginaceae family, depending on their shapes, sizes, and a number of colpates. 

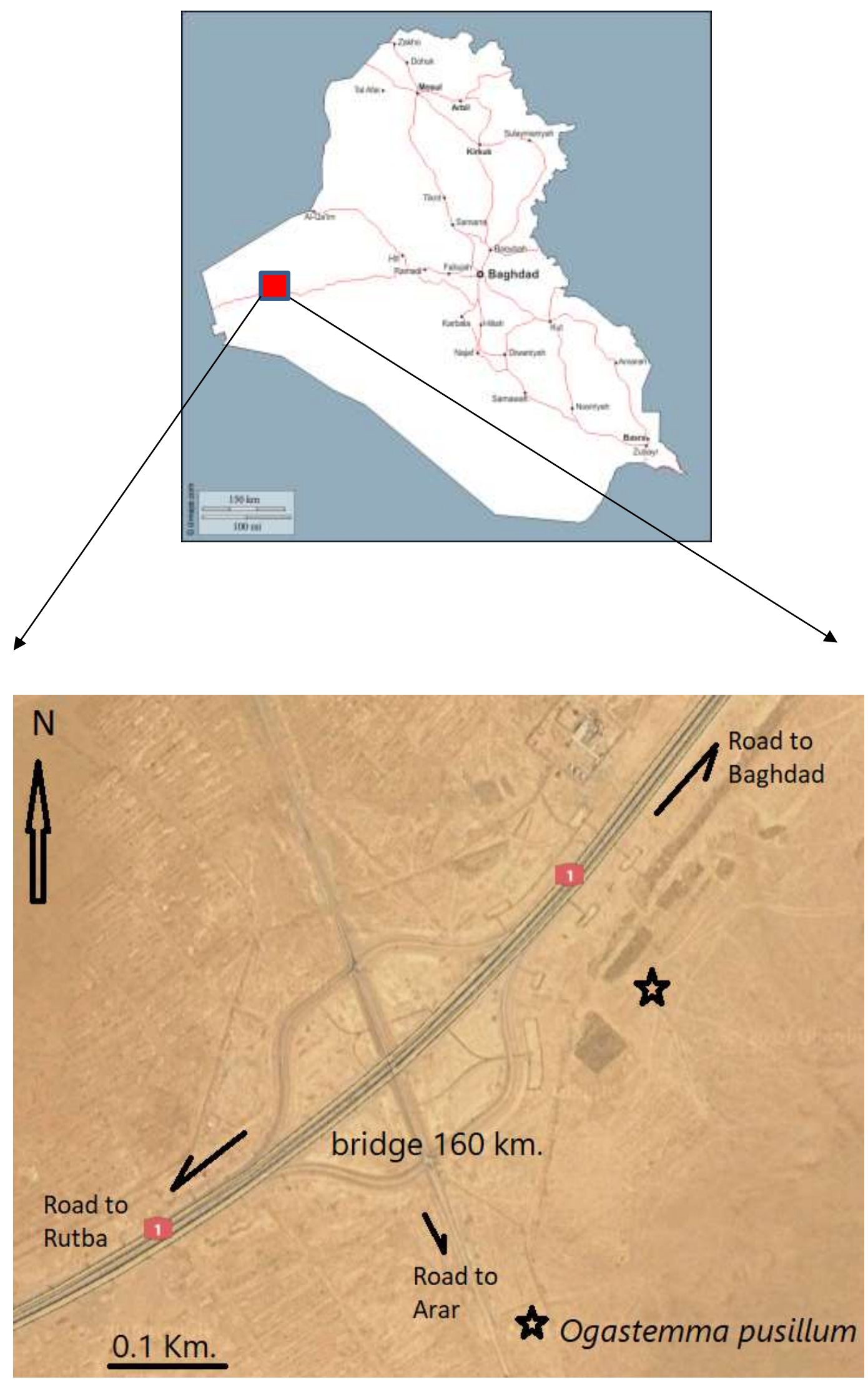

Figure 1. Satellite image of studied region $(160 \mathrm{~km}$. west of Ramadi- Iraq) 
Table 1. The vegetative and reproductive characters of the studied Ogastemma pusillum.*

\begin{tabular}{|c|c|c|c|c|c|}
\hline \multirow[b]{2}{*}{1} & \multirow[b]{2}{*}{ Leaves (mm.) } & Basal leaves size & Shape & Cauline leaves size & Shape \\
\hline & & $32.0 \times 1.7$ & $\begin{array}{c}\text { Liner-very } \\
\text { narrowly } \\
\text { lanceolate }\end{array}$ & $19.0 \times 2.2$ & $\begin{array}{l}\text { Narrowly } \\
\text { lanceolate }\end{array}$ \\
\hline \multirow{3}{*}{2} & \multirow{3}{*}{$\begin{array}{c}\text { Inflorescences } \\
(\mathbf{m m} .)\end{array}$} & Bract size & $\begin{array}{l}\text { Inflorescence } \\
\text { length }\end{array}$ & Number of flowers & $\begin{array}{l}\text { Peduncle } \\
\text { length }\end{array}$ \\
\hline & & 7. $3 \times 1.3$ & 43 & 10 & 12 \\
\hline & & Calyx tube size & Calyx lobed size & Sepals & Indumentum \\
\hline \multirow[t]{2}{*}{3} & $\begin{array}{l}\text { Calyx } \\
\text { (mm.) }\end{array}$ & $0.8 \times 1.0$ & $3.3 \times 0.9$ & unequal & hispid \\
\hline & & Corolla tube size & Corolla limb size & Limb shape & Colour \\
\hline \multirow[t]{2}{*}{4} & $\begin{array}{c}\text { Corolla } \\
\text { (mm.) }\end{array}$ & $3.0 \times 0.9$ & $0.7 \times 0.7$ & circular & white \\
\hline & & Anther size & Shape & Filament size & Attachment \\
\hline \multirow[t]{2}{*}{5} & $\begin{array}{l}\text { Androecium } \\
(\mathbf{m m} .)\end{array}$ & $0.7 \times 0.4$ & Ovoid- ellipsoid & $0.40 \times 0.09$ & dorsifixed \\
\hline & & Ovary size & Ovary locules & $\begin{array}{l}\text { Style } \\
\text { Size }\end{array}$ & Stigma size \\
\hline 6 & $\begin{array}{l}\text { Gynoecium } \\
\text { (mm.) }\end{array}$ & $0.5 \times 0.6$ & 4 & $0.34 \times 0.13$ & $0.17 \times 0.23$ \\
\hline 7 & $\begin{array}{l}\text { Fruiting calyx } \\
\text { and Fruits } \\
\quad(\mathbf{m m} .)\end{array}$ & $\begin{array}{c}\text { Fruiting calyx } \\
\text { tube } \\
\text { Size } \\
1.0 x 1.3\end{array}$ & $\begin{array}{c}\text { Fruiting calyx } \\
\text { lobed } \\
\text { size } \\
3.9 \times 1.1\end{array}$ & Nutlet size & $\begin{array}{c}\text { Densely } \\
\text { verrucose }\end{array}$ \\
\hline \multirow{2}{*}{8} & & Seed size (mm.) & Shape & $\begin{array}{c}\text { Equatorial axis } \\
\qquad(\mu \mathrm{m} .)\end{array}$ & $\begin{array}{c}\text { Polar axis } \\
(\mu \mathrm{m} .)\end{array}$ \\
\hline & Pollen grains & $1.2 \times 0.7$ & pyriform & 13.2 & 11.9 \\
\hline
\end{tabular}



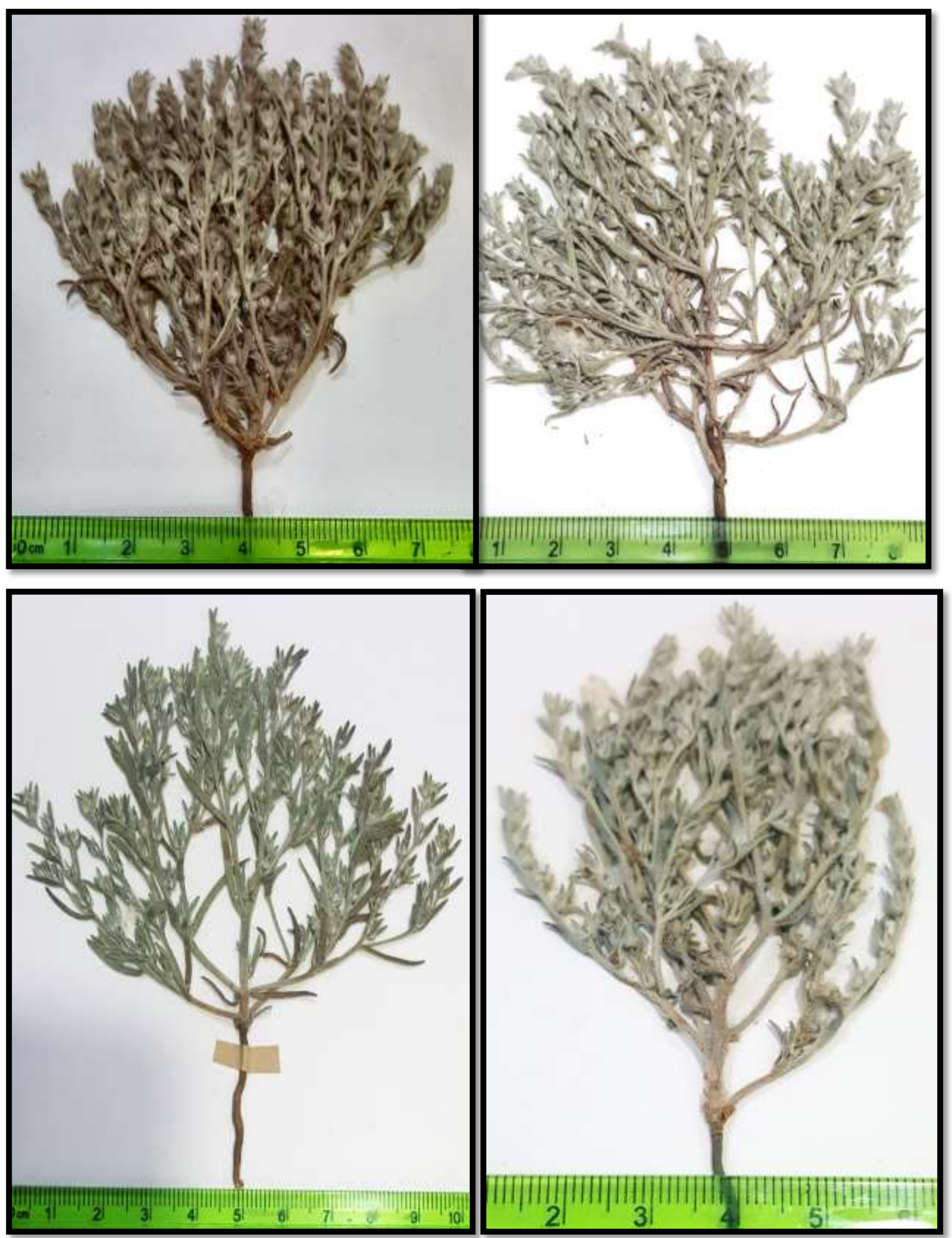

Plate 1. Photogrsphs of herbarium samples for Ogastemma puillum.

Anatomical study: Stomatal complex anomocytic type, in both surfaces of the blade, more in abaxial, stoma narrowly elliptic, $6-7$ $\mu \mathrm{m}$., guard cells kidney like 12-13 x 4-5 $\mu \mathrm{m}$. (plate 4), note that some species, such as Portulaca oleracea which contained two different patterns of stomatal complex (4). The transverse section of the stem is 
curricular, diameter $880 \mu \mathrm{m}$., the epidermis (e) is composed of rectangular cells, the upper surface is covered with cuticle and contains non - glandular hairs. The cortex is 4- 6 layered and consists of chlorenchyma (ch) arranged semi-circular, leaving some areas of collenchyma (co) with 3-4 layered, the singlelayered endodermis consists of ellipsoid cells. The vascular cylindrical is very wide and contains 7-9 vascular bundles, distributed regularly, bundle cap is 4-5 layered of sclerenchyma (s) cells. The phloem (ph) is 3-5 layered, the remains of the cambium are not distinguishable. The xylem (x) was composed of vascular units with a thickness of 80-100 $\mu \mathrm{m}$. . The pith (p) consists of layer spherical or polyhedral parenchymatic cells, with thickness 450-500 $\mu \mathrm{m}$., these cells are thin-walled (Plate $5)$.

Type: ALGERIA. Biskra, surles collines incultes, 10 May 1853, Balansa 1035.

\section{Specimens studied}

DWD: $160 \mathrm{~km}$. west of Ramadi, highway, 280 m. alt., 4/ 5/ 2019, M.O.Mousa and Herbarium staff, 60264 (BAG)., $155 \mathrm{~km}$. west of Ramadi, highway, 275m. . alt., 24 / 5/ 2019, M.O. Mousa and Herbarium staff, 60265 (BAG).

\section{Geographical distribution}

Ogastemma is a monotypic genus, in 1982 researcher Brumitt (9) suggested this name for the species under study. Ogastemma pusillum seems to be mainly a Saharo - Sindian element distribution, it was distributed a very long time ago in sandy soils from sea level to $1000 \mathrm{~m}$ in North Africa, Algeria, Tunisia, Libya, Mauritania, Egypt, and Morocco, according to Zaeifi and Rammazanzade (37). In Jordan, it is considered an endangered species that has been placed in red list (34), while it has been able to increase its geographic distribution through continuous migration and success in new and appropriate environments, in 1994, it was first time recorded in Kuwait (9), Ghazanfar (15) recorded the presence of the species in 1998 in Saudi Arabia, only one year later (1999), the species was recorded in United State of Emirates (7), Zaeifi and Ramazanzade (37) recorded the same species in 2007 in Iran, and in the same year, the species was first recorded in Qatar (29). This new species distribution was adapted to new world climate changes, especially in temperature, this is confirmed by Nathan and Muller-Landau (28), and Schurr et al., (32) when they said that long-distance dispersal in central to species expansion following climate change. Mendoza- Diaz (23) said in his study of the Boraginaceae family that the characteristics of the Echinochilon genus are reminiscent of the Ogastemm genus, this is because of the similarity of the two genera and their genetic convergence, while Langstrom (19) studied the two genera and gave an accurate description of them, referring to the basic characteristics of isolating the genera, the recall from them the Echiochilon characterized by being perennial, shrublet, up to $100 \mathrm{~cm}$., glabrous to glandular-hairy, the calyx is much smaller than the corolla, nutlets ovoid to cordate, smooth, white or reddish, pollen grains rectangular to square, 2-3 colporate. All Iraqi references of wild plants did not indicate to the presence of Ogastemma in Iraq, such as Flora of Lowland Iraq (30), and Al-Rawi (5) listing of geographical distribution of wilad plants in Iraq, also a comprehensive survey of the Iraqi Herbarium did not find any specimen of the genus, therefore, this study is confident of recording the genus for the first time in Iraq. 

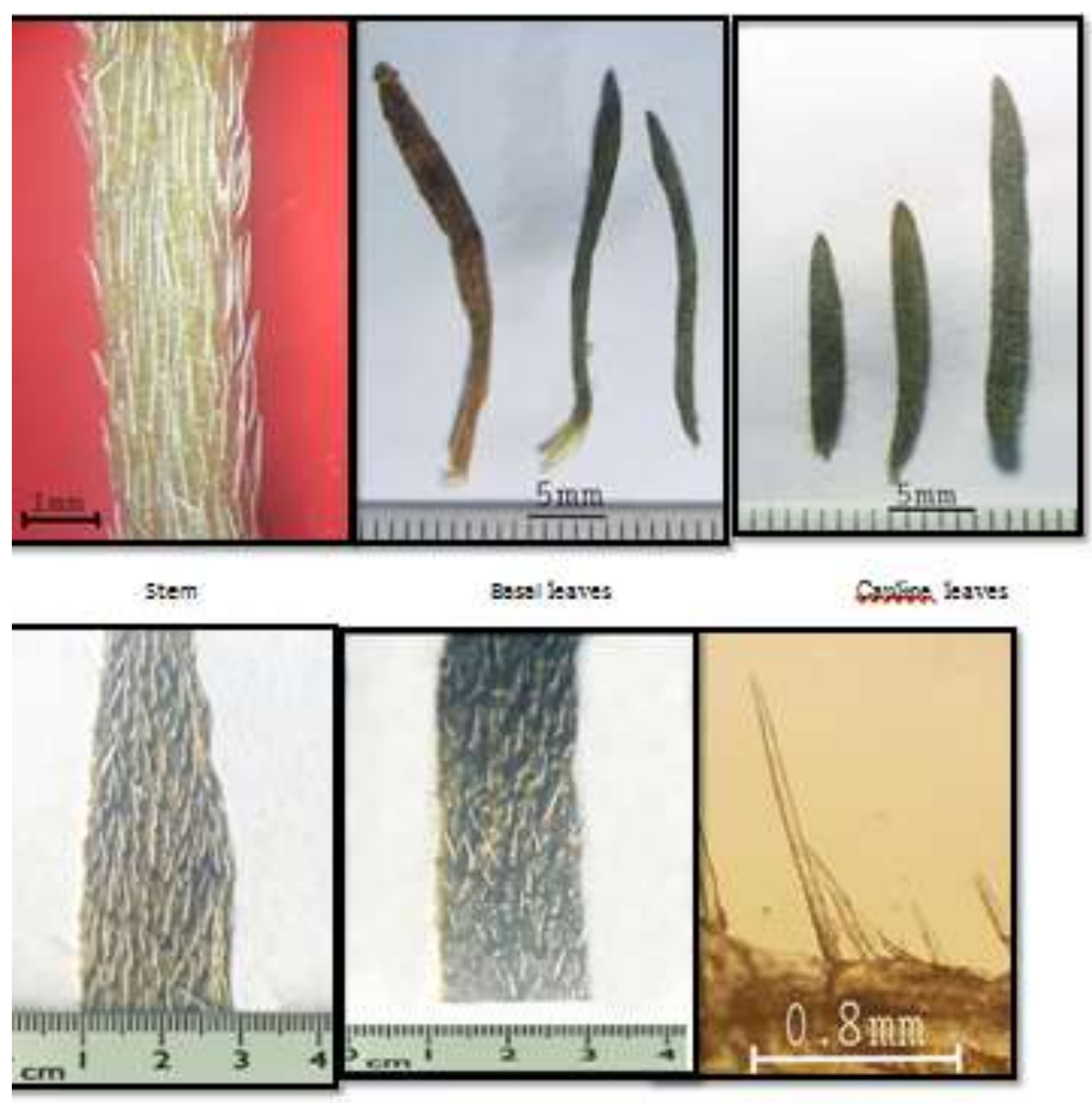

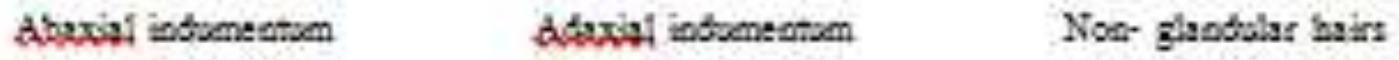

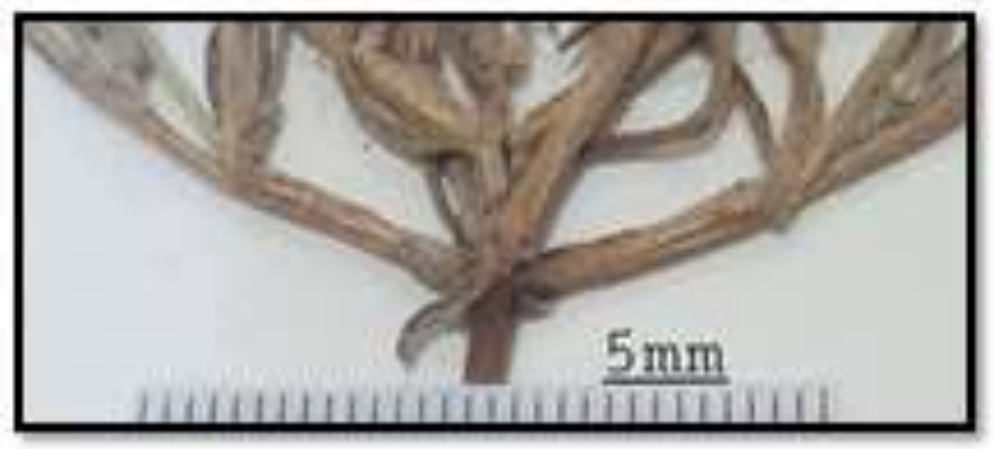

Stem branched

Plate 2. Vegetative organs of $O$. pusillum. 

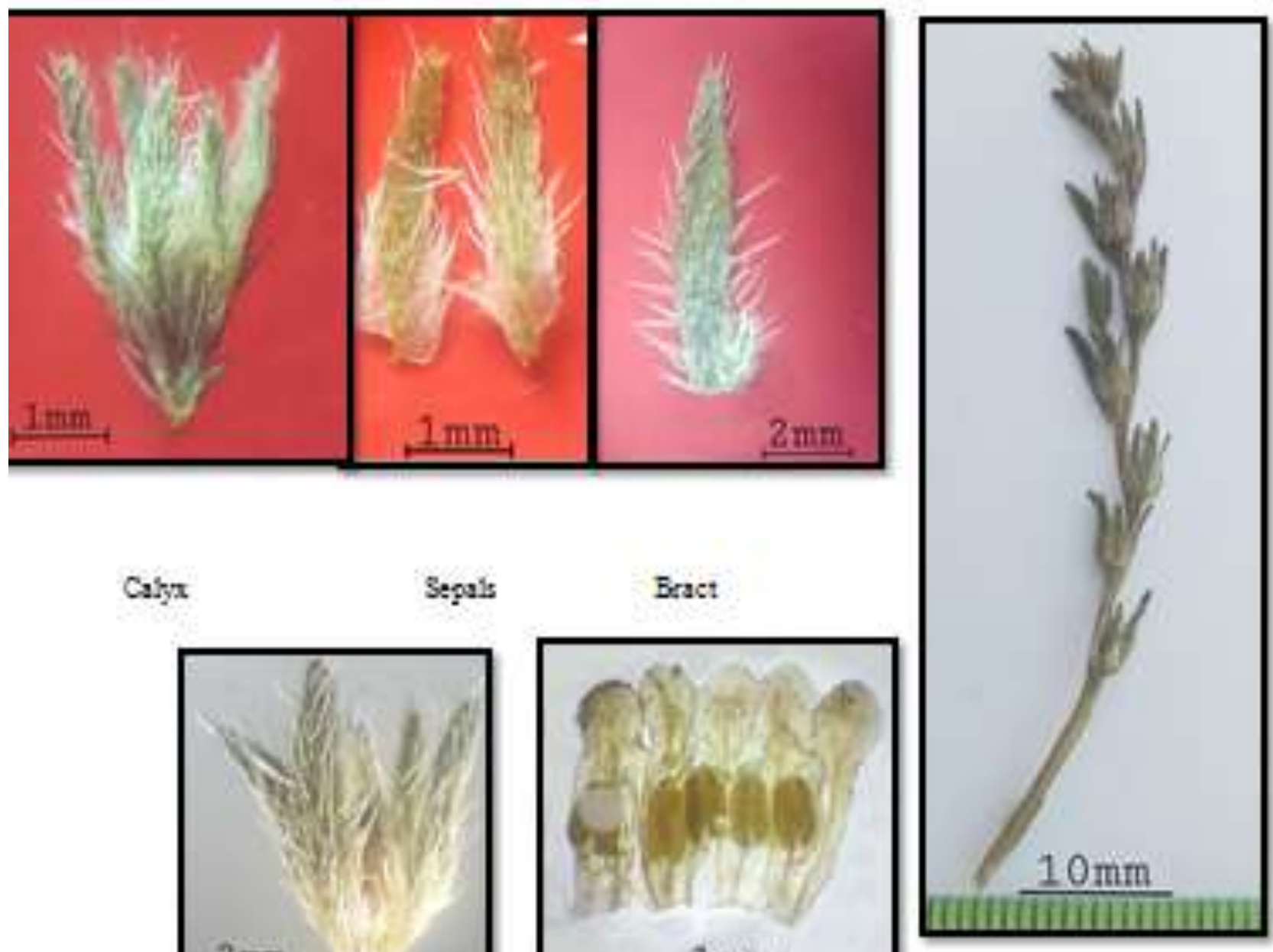

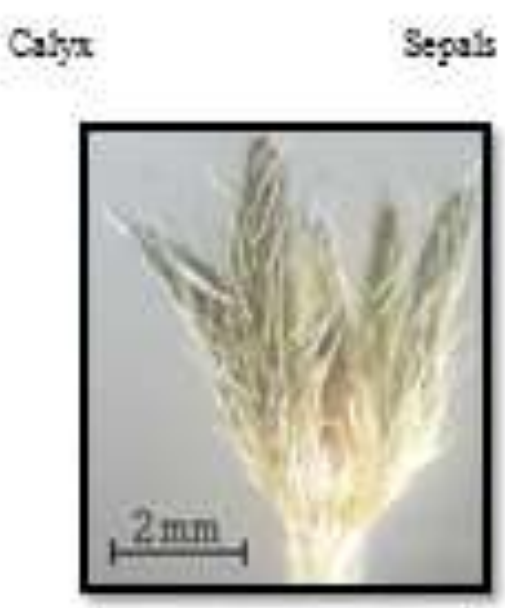

Fruiting calyx
Bract

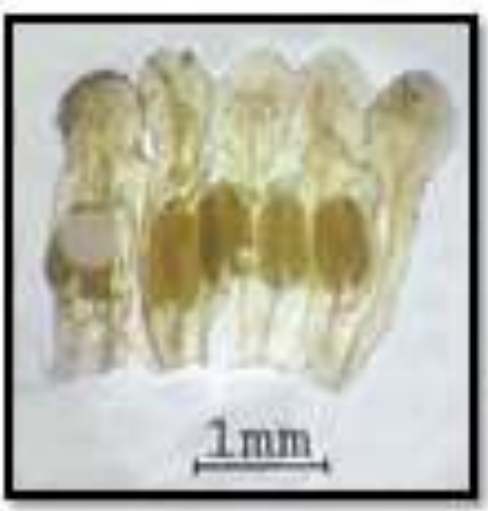

Opeaed Coroth and Stamen
Infloresceace
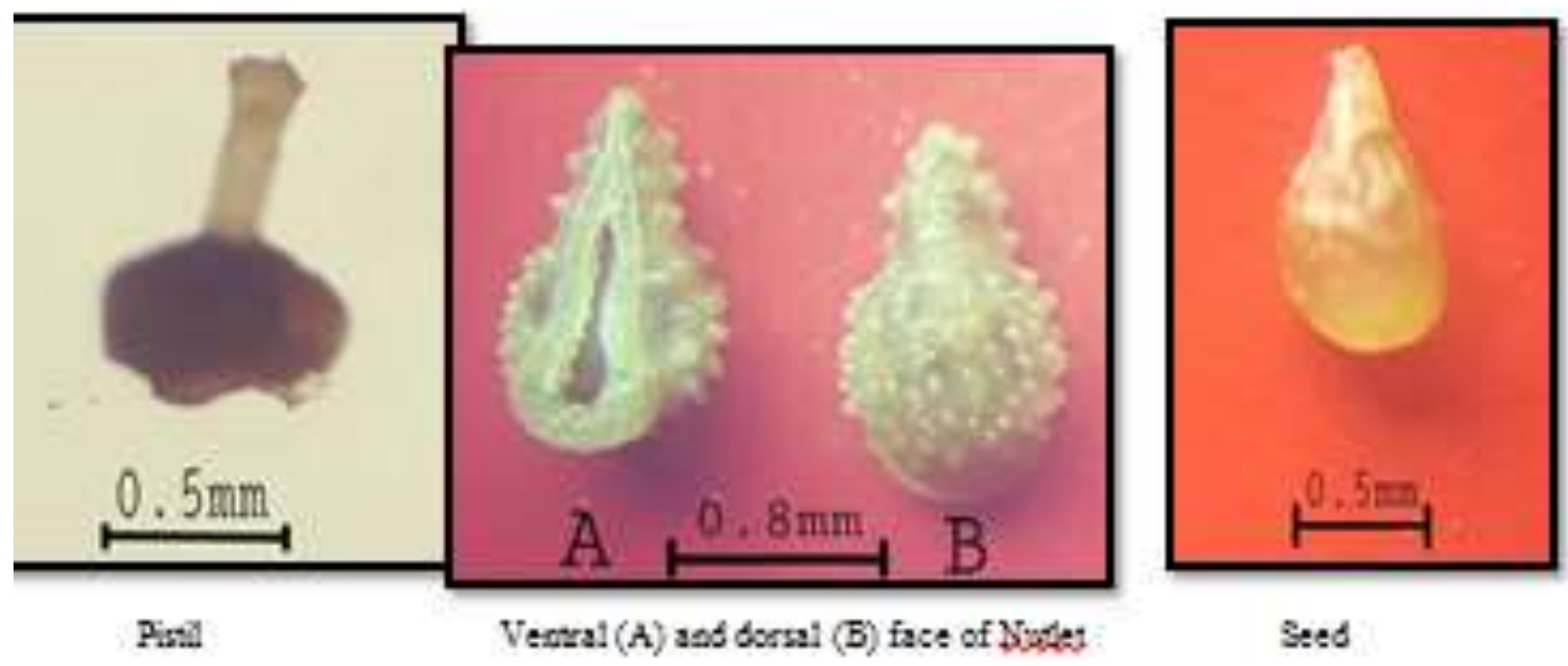

Seed

Plate 3. Reproductive organs of $\boldsymbol{O}$. pusillum. 


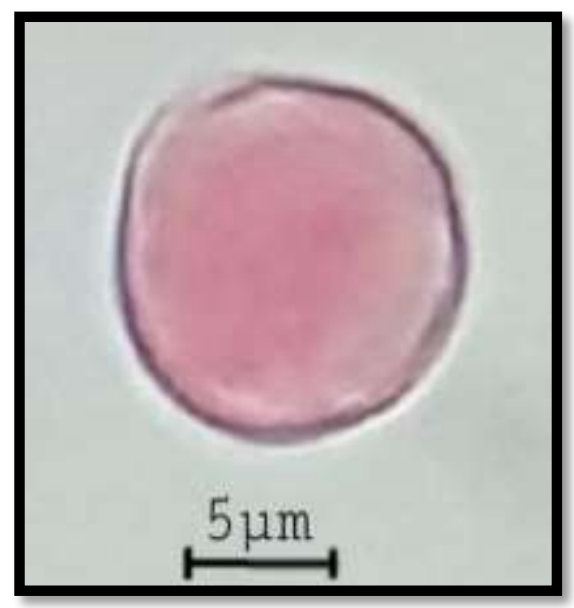

Equatorial view

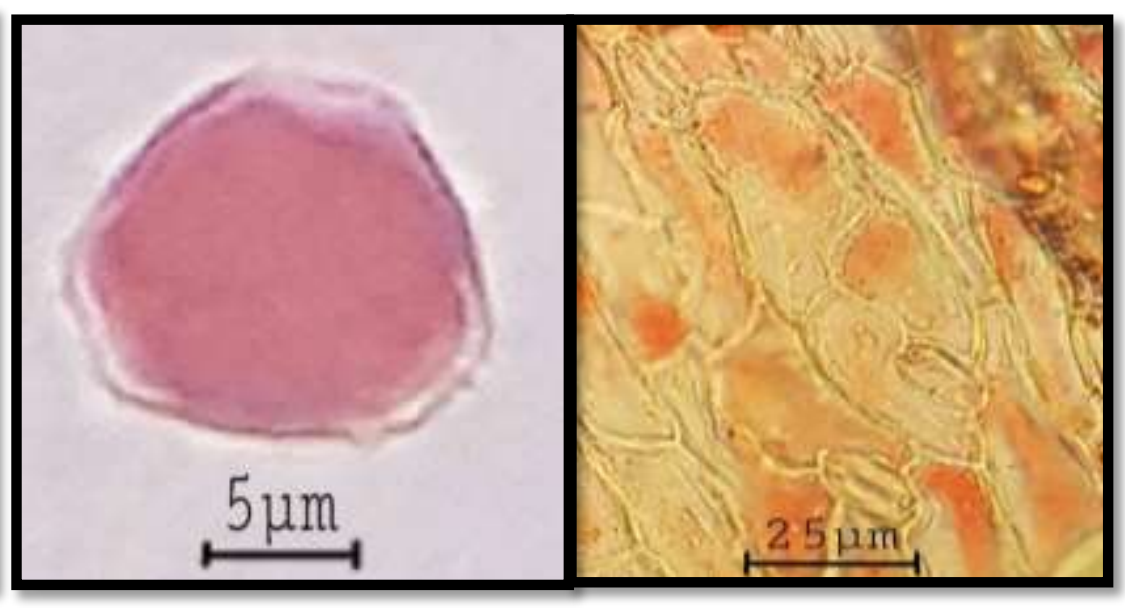

Polar view

Leaf epidermis

Plate 4. Pollen grains $(1000 \mathrm{x})$ and Stomatal complex $(100 \mathrm{x})$ of $O$. pusillum.

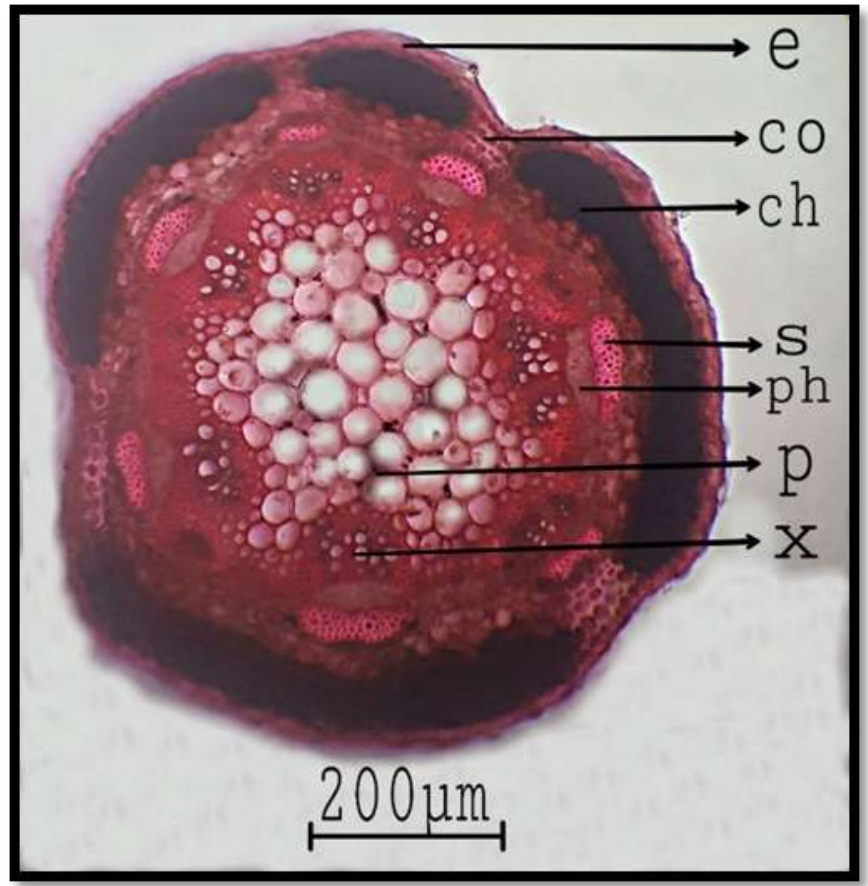

Plate 5. Transverse section of stem $(100 \mathrm{x})$ of $O$. pusillum.

\section{REFERENCES}

1-Abdullah, M. T. 2017. Conserving the biodiversity of Kuwait through DNA barcoding the Flora $\mathrm{Ph}$. D. Thesis. Univ. of Edinburgh. pp: 317

2-Alkhuzai, J. 2015. Biodiversity baseline assessment report. Bahrain National Bio3 diversity Strategy and Action Plan, Supreme Council for Environment, Kingdom of Bahrain, pp: 109.

3-Al- Musawi, A.H.E. 1987. Plant taxonomy. Univ. of Baghdad, (In Arabic), pp: 379.

4- Al-Newani, H. R. H. 2019. Systematics significance of morphological and anatomical diversity of Portulaca oleracea. Iraqi Journal of Agricultural Sciences, 50(5), 1383-1389
5-Al-Rawi, A. 2014. Wild Plants of Iraq with their Distribution. $3^{\text {rd }}$ ed.Tech. bull. No.14 Gen. Agr. Res. Proj. Ministry of Agriculture, Government Press. pp: 232.

6-Al-Shehbaz, I. A. 1991. The genera of Boraginaceae in the Southeastern United States. Journal of the Arnold Arboretum. Supplementary Series, 1, 1-169

7-Böer, B. and S. A. Chaudhary. 1999. New records for the Flora of the United Arab Emirates. Willdenowia, 29 (1/2), 159-166.

8-Boulos, L. 2000. Flora of Egypt, (Geraniaceae-Boraginaceae) Cairo. AlHadara Pub, Vol.: 2, pp:352.

9-Boulos, L. and M. Al-Dosari. 1994. Checklist of the Flora Kuwait. Journal of the 
University of Kuwait (science).

Kuwait, 21(2);203-217.

10-Brummitt, R. K. 1982. Ogastemma, a new name for Megastoma (Boraginaceae). Kew Bulletin, Journal Article, 36 (4),679- 680.

11-Cecchi, L. and F. Selvi. 2015. Synopsis of Boraginaceae subfam. Boraginoideae tribe Boragineae in Italy. Plant Biosystems-An International Journal Dealing with all Aspects of Plant Biology, 149(4), 630-677.

12-Chacón, J.; F. Luebert and M. Weigend. 2017. Biogeographic events are not correlated with diaspore dispersal modes in Boraginaceae. Frontiers in Ecology and Evolution, 5 (26), 1-14.

13-El- Sheikh, M. A. and G. A. Abbadi. 2004. Biodiversity of plant communities in the Jalaz-zor National Park, Kuwait. Kuwait Journal of Science and Engineering, 31(1), 77-106

14-Gess, S. K. and P. A. Roosenschoon. 2016. A preliminary survey of flower visiting by aculeate wasps and bees in the Dubai Desert Conservation Reserve, UAE. Journal of Hymenoptera Research, 52, 81-141.

15-Ghazanfar, S. A. 1998. Vegetation of the Plains. In Vegetation of the Arabian Peninsula. Springer, Dordrecht, pp: 302

16-Hacioğlu, B. T. and S. Erik. 2011. Phylogeny of Symphytum L.(Boraginaceae) with special emphasis on Turkish species. African Journal of Biotechnology, 10(69), 15483-15493.

17-Hammouda, S. A.; M. Weigend; F. Mebrouk; J. Chacón; M. Bensalah; H. J. Ensikat and M. Adaci. 2015. Fossil Nutlets of Boraginaceae from the continental Eocene of Hamada of Méridja (Southwestern Algeria): The first fossil of the Borage family in Africa. American journal of botany, 102(12), 2108-2115.

18-Karim, F.M. and N.M. Fawzi. 2007. Flora of the United Arab Emirates, University. By Publications Department, Abu Dhabi Vol.: 2, pp: 502.

19-Långström, E. 2002. Systematics of Echiochilon and Ogastemma (Boraginaceae), and the phylogeny of Boraginoideae (Doctoral dissertation, Acta Universitatis Upsaliensis). pp:34

20-Långström, E. and M. W. Chase. 2002. Tribes of Boraginoideae (Boraginaceae) and placement of Antiphytum, Echiochilon,
Ogastemma and Sericostoma: a phylogenetic analysis based on atpB plastid DNA sequence data. Plant Systematics and Evolution, 234 (14), 137-153.

21-Le Floch, É.; L. Boulos and E. Vela. 2010. Catalogue synonymique commenté de la Flore de Tunisie. Simpact. pp:505

22-Lönn, E. 1999. Revision of the three Boraginaceae genera Echiochilon, Ogastemma and Sericostoma. Botanical journal of the Linnean Society, 130(3), 185-259

23-Mendoza-Diaz, N.; H. Flores-Olvera; M. G. Simpson and M. J. Moore. 2018. A new and unusual endemic species from the Chihuahuan Desert, Mexico: Antiphytum geoffreyi

(Boraginaceae, Echiochiloideae). Phytotaxa, 367(3), 275-283 24-Mousa, M. O. 2019. A New Record for The Flora of Iraq: Lotus garcinii DC. (Papilionaceae). Iraqi Journal of Agricultural Sciences, 50(3), 951-959

25-Mousa, M. O. 2004. A new record of Echium rauwolfii (Boraginaceae) in Iraq. Journal of science and engineering, 4 (1): 7-13 26-Mousa, M. O. 2002. A new record of Arnebia hispidissima (Boraginaceae) in Iraq. Journal of science and engineering, 2 (1): 259267

27-Mustafa, A.; H. J. Ensikat and M. Weigend. 2018. Mineralized trichomes in Boraginales: complex microscale heterogeneity and simple phylogenetic patterns. Annals of botany, 121(4), 741-751.

28-Nathan, R. and H. C. Muller-Landau. 2000. Spatial patterns of seed dispersal, their determinants and consequences for recruitment. Trends in ecology \& evolution, 15(7), 278-285

29-Norton, J.; S. A. Majid; D. Allan; M. AlSafran; B. Böer and R. Richer.2009. An illustrated checklist of the flora of Qatar. Gosport: Browndown Publications pp: 96.

30-Rechinger, K.H. 1964. Flora of Lowland Iraq. Vela von. J. Cramer wenheim. pp:746.

31-Sardar, A. S. 2018. A New Record of Paracaryum shepardii Post et Beauv. (Boraginaceae) in Iraq. Diyala Journal for Pure Science, 14 (2), 174-186

32-Schurr, F. M.; O. Spiegel; O. Steinitz; A. Trakhtenbrot; A. Tsoar and R. Nathan .2018. Long-distance seed dispersal. Annual Plant Reviews online, 204-237 
33-Taia, W. K. 2006. Family boraginaceae: Hair variations and their significance in the systematic of the genera. Asian J. Plant Sci., 5(3), 441-454

34-Taifour, H. 2017. Jordan plants red list, VOL. 2. Royal Botanic Gardan, Amman, Jordan. pp: 936

35-Verloove, F. 2013. Non-native vascular plants from Canary Islands (Spain): nomenclatural and taxonomical adjustments. Lagascalia, 33 (1).19-35 36-Weigend, M.; A. Mustafa and H. J. Ensikat. 2018. Calcium phosphate in plant trichomes: the overlooked biomineral. Planta, 247 (1), 277-285

37-Zaeifi, M. and S. Ramazanzade. 2009. Ogastemma Brumitt (Boraginaceae), A New Genus for the Flora of Iran. Iran. J. Bot, 15(2), 172-174. 